\title{
A Study on the Parameters that Affect Cyber Security
}

\author{
Mayur Shukla* \\ Student, Balaji Institute of Management and Human Resource Development, Pune, India \\ *Corresponding author: mayurshukla9@gmail.com
}

\begin{abstract}
Cyber Security plays an important role in the field of computer science information technology. Securing the information from have become one of the biggest challenges in the present day. This study will use primary data collection tools (questionnaire) to collect information from respondents. This paper mainly focuses on challenges faced by cyber security. It also focuses on latest about the cyber security techniques and the trends changing the face of cyber security. cyber security is becoming very important topic to work on and covering various different type of cyber-attacks.
\end{abstract}

Keywords: Cyber-crime, Machine learning.

\section{Introduction}

Today any human being can send and receive any form of data may be an audio or video just by the internet. for the batter transmission of data, we have to ensure cyber security, which prevent the leakage of the information. In today's technical environment technologies are changing day by day. So because of these new technologies we are unable to safeguard our private information in a very effective way and so these days cybercrime are increasing at higher speed.

Today we are doing more than 50 percent of total transactions online, so this field of internet need more security for batter and secure transaction. Hence cyber security has become the most important issue. The scope of cyber security is not just limited to securing the information in IT industry but also to various other fields like cyber space etc.

\section{Research problem}

The growing list of cyber-crime includes crimes that have been made possible by computers. here we will be discussing about the basic mistakes that make our system vulnerable to be hacked in.

\section{Research Objective}

- Our objective to achieve system security from malicious code, intrusion and spam.

- To study factors which have an impact on Cyber security.

\section{Hypothesis}

$\mathrm{H} 0$ : There is no difference between gender when considering he tried hacking.
H1: There is difference between gender when considering he tried hacking.

H0: There is no difference between age groups when considering does they ever suffer by hacking.

H1: There is difference between age groups when considering does they ever suffer by hacking.

H0: There is no significant impact of using open internet connection on hacking of the social media account.

H1: There is significant impact of using open internet connection on hacking of the social media account.

Review of literature

(G. Nikhita Reddy, G. J. Ugander Reddy, 2014), The study discusses about the challenges in cyber security and how to prevent fraud, intrusion, spam, malicious code in effective manner. As new technologies like cloud, web based online transaction are growing we need cyber security.

(Vitaly ford and Ambareen Siraj, 2014), this study talks about machine learning algorithms that we use in cyber security. Study have discussed about Logistic Regression (LR), Classification and Regression Trees (CART) for phishing detecting and network intrusion detection.

(Uzma Afzal, Tariq Mahmood, 2013), this study discuss about how big data analytics helps us to predict any malicious activity. analytics can assist network managers particularly in monitoring and surveillance of real time malicious code and suspicious pattern.

(Subil Abraham, Suku Nair,2015), this study discusses about different type of model and matrix that we use to detect and prevent cyber attracts. this paper also discusses about attract graph, markov model, CSVV matrix domain.

(Thomas oseku-afful, 2016) this study discuss about the effect of digital transformation and how digitalization increasingly effecting our data security.

\section{Research Methodology}

Research design: The purpose of the study is to gain knowledge about the basic activity that compromise the system security and support data breach.

Research approach: Respondents are the user that were ready to co-operate. To collect data, we gone through the survey method.

Data collection: The primary data is collected from the 
students of sri balaji university and data is collected through survey method.

Data analysis method: The data analysis of the research will be mostly represented in qualitative manner.

\section{Data Analysis}

Table 1

\begin{tabular}{|l|c|c|c|c|c|}
\hline \multicolumn{7}{|c|}{ Table 1 } \\
\hline & Value & df & $\begin{array}{c}\text { Asymptotic } \\
\text { Significance (2- } \\
\text { sided) }\end{array}$ & $\begin{array}{r}\text { Exact } \\
\text { Sig. (2- } \\
\text { sided) }\end{array}$ & $\begin{array}{r}\text { Exact } \\
\text { Sig. (1- } \\
\text { sided) }\end{array}$ \\
\hline $\begin{array}{l}\text { Pearson Chi- } \\
\text { Square }\end{array}$ & $3.662^{\mathrm{a}}$ & 1 & .056 & & \\
\hline $\begin{array}{l}\text { Continuity } \\
\text { Correction }\end{array}$ & 2.437 & 1 & .118 & & \\
\hline $\begin{array}{l}\text { Likelihood } \\
\text { Ratio }\end{array}$ & 3.666 & 1 & .056 & & .080 \\
\hline $\begin{array}{l}\text { Fisher's Exact } \\
\text { Test }\end{array}$ & 56 & & & & \\
\hline $\begin{array}{l}\text { N of Valid } \\
\text { Cases }\end{array}$ & 56 & & & & \\
\hline
\end{tabular}

Since $\mathrm{p}$ value is greater than 0.05 (in case of knowing current prices) we do not reject null hypothesis and conclude that there is no difference between gender when considering he tried hacking.

Table 2

\begin{tabular}{|l|l|l|l|}
\hline \multicolumn{4}{|c|}{ Chi-Square Tests } \\
\hline & Value & df & Asymptotic Significance (2-sided) \\
\hline Pearson Chi-Square & $20.621^{\mathrm{a}}$ & 6 & .002 \\
\hline Likelihood Ratio & 23.129 & 6 & .001 \\
\hline N of Valid Cases & 56 & & \\
\hline
\end{tabular}

Since $\mathrm{p}$ value is lesser than 0.05 (in case of knowing current prices) we reject null hypothesis and conclude that There is difference between age groups when considering does they ever suffer by hacking.

Table 3

\begin{tabular}{|l|l|l|l|l|l|}
\hline \multicolumn{7}{|c|}{ Chi-Square Tests } \\
\hline & Value & df & $\begin{array}{c}\text { Asymptotic } \\
\text { Significance (2- } \\
\text { sided) }\end{array}$ & $\begin{array}{c}\text { Exact } \\
\text { Sig. (2- } \\
\text { sided) }\end{array}$ & $\begin{array}{c}\text { Exact } \\
\text { Sig. (1- } \\
\text { sided) }\end{array}$ \\
\hline $\begin{array}{l}\text { Pearson Chi- } \\
\text { Square }\end{array}$ & $.042^{\mathrm{a}}$ & 1 & .838 & & \\
\hline $\begin{array}{l}\text { Continuity } \\
\text { Correction }\end{array}$ & .000 & 1 & 1.000 & & \\
\hline $\begin{array}{l}\text { Likelihood } \\
\text { Ratio }\end{array}$ & .042 & 1 & .838 & & \\
\hline $\begin{array}{l}\text { Fisher's Exact } \\
\text { Test }\end{array}$ & & & & 1.000 & .553 \\
\hline $\begin{array}{l}\text { N of Valid } \\
\text { Cases }\end{array}$ & 56 & & & & \\
\hline
\end{tabular}

Since $p$ value is greater than 0.05 (in case of knowing current prices) we do not reject null hypothesis and conclude that there is no significant impact of using open internet connection on hacking of the social media account.

\section{Findings and Suggestions}

In this study we tested three hypothesis to find out the impact of different aspect on cyber security. We have seen the impact the use of open internet connection to cyber attract on social media account and conclude that no significant impact of using open internet connection on hacking of the social media account.

We have also seen that does gender have any impact on whether they tried hacking and concluded that there is no difference between gender when considering he tried hacking. we also seen that is there any particular age group suffer by hacking or not and concluded that There is difference between age groups when considering does they ever suffer by hacking.

Cyber-crimes are increasing daily to prevent can use artificial intelligence and machine learning algorithms to prevent cyber attracts. also to reduce hacking we have to be care full about the operating system that we using in system.

\section{Limitations and Conclusion}

Computer security is a vast topic that is becoming more important because the world is becoming highly interconnected thought internet.

Cyber-crime continues to diverge down different paths with each New Year that passes. The latest and disruptive technologies, along with the new cyber tools, machine learning, big data analytics and threats that come to light each day, are challenging organizations with not only how they secure their infrastructure. There is no perfect solution for cybercrime. We cannot prevent all types of cyber threat because of advancement in technology but upgrade system to prevent most of them.

\section{Further Research Directions}

In this research paper we have discussed about the very basic mistake that we do without knowing the output on our information security.

\section{References}

[1] A. Sophos Article 04.12v1.dNA.

[2] James Lyne, "Eight trends changing network security."

[3] Sunit Belapure, Nina Godbole, "Cyber Security: Understanding Cyber Crimes."

[4] Audrie Krause, "Computer Security Practices in - A Net Action Report."

[5] Luis Corrons, "A Look back on Cyber Security 2012," Panda Labs.

[6] G. Nikhita Reddy, G. J. Ugander Reddy, "Study of Cloud Computing in Health Care Industry," in International Journal of Scientific \& Engineering Research, Volume 4, September 2013.

[7] "Safety Critical Systems - Next Generation," IEEE Security and Privacy Magazine - IEEECS, July/ Aug. 2013.

[8] Avanthi Kumar, "Cyber security in Malaysia," CIO Asia, September 3rd, H1 2013

[9] E. Frank, Data Mining: Practical machine learning tools and techniques, 3rd Edition, Morgan Kaufmann, 2011.

[10] H. Karau, A. Konwinski, P. Wendell and M. Zaharia, Learning Spark: Lightning-Fast Big Data Analytics, O'Reilly Media, Inc., 2015.

[11] M. Tavallaee, E. Bagheri, W. Lu and A. A. Ghorbani, "A detailed analysis of the KDD CUP 99 data set," in the Second IEEE Symposium on Computational Intelligence for Security and Defence Applications, 2009.

[12] R. Megha and V. Pareek, "Spam Mail Detection through Data Mining-A Comparative Performance Analysis," International Journal of Modern Education and Computer Science, vol. 5, no. 12, pp. 31-39, 2013. 